\title{
The attitude of Brazilian federal police officers towards firearms
}

\author{
Alessandra Borba 1 \\ Adalmir de Oliveira Gomes 1 \\ 1 Universidade de Brasília / Programa de Pós-Graduação em Administração, Brasília / DF - Brazil
}

This research deals with one of the most problematic themes in the Brazilian public security agenda, firearm control. Since the publication of the Statute of the Disarmament in 2003, the Federal Police (FP) has been responsible for controlling firearm possession of the civilian population. Thus, FP officers become central players in firearm control policies in Brazil. In this research, we investigate the attitude of Brazilian FP officers towards firearms and what explains this attitude. We collected data from 800 police officers from different positions working in all regions of the country. The results show that police officers believe that firearm possession is an individual right, but firearms do not protect against crime. The results also show that the officers' attitude towards firearms is influenced by their position and their experience with firearms. The article presents the study's implications for management theory and practice.

Keywords: Brazilian Federal Police; police officers; attitude; firearms; public security.

\section{A atitude de policiais Federais brasileiros em relação às armas de fogo}

Esta pesquisa trata de um dos temas mais problemáticos da agenda da segurança pública brasileira, o controle de armas de fogo. Desde a publicação do Estatuto do Desarmamento, em 2003, a Polícia Federal (PF) é responsável pelo controle da posse e porte de armas de fogo pela população civil. Assim, os oficiais da PF passaram a ser atores centrais nas políticas de controle de armas de fogo no Brasil. Nesta pesquisa, investigamos a atitude dos oficiais brasileiros de PF em relação às armas de fogo e o que explica essa atitude. Coletamos dados de 800 policiais, de diferentes cargos e atuantes em todas as regiões do país. Os resultados mostram que os policiais acreditam que possuir armas de fogo é um direito individual, mas que a arma não protege contra o crime. Os resultados também mostram que a atitude dos policiais em relação às armas de fogo é influenciada pelo cargo ocupado na PF e pela experiência do policial com armas de fogo. Ao final, são apresentadas as implicações do estudo para a teoria e prática gerencial.

Palavras-chave: Polícia Federal brasileira; policiais; atitude; armas de fogo; segurança pública.

\section{La actitud de los agentes de la Policía Federal brasileña en relación con las armas de fuego}

Esta investigación aborda uno de los temas más problemáticos de la agenda de seguridad pública brasileña, el control de armas de fuego. Desde la publicación del Estatuto de Desarme, en 2003, la Policía Federal (PF) se ha encargado de controlar la tenencia y porte de armas de fuego por parte de la población civil. Así, los oficiales de la PF se convierten en actores centrales de las políticas de control de armas de fuego en Brasil. Investigamos la actitud de los oficiales de la PF brasileña hacia las armas de fuego y qué explica esta actitud. Recopilamos datos de 800 policías de diferentes cargos y que operan en todas las regiones del país. Los resultados muestran que los agentes de policía creen que la tenencia de armas de fuego es un derecho individual, pero que las armas no protegen contra el crimen. Los resultados también muestran que la actitud de los policías hacia las armas de fuego está influenciada por el cargo que ocupa y por la experiencia del policía con las armas de fuego. Al final, se presentan las implicaciones del estudio para la teoría y la práctica de la gestión.

Palabras clave: Policía Federal brasileña; policías; actitud; armas de fuego; seguridad pública. 


\section{INTRODUCTION}

The discussion on facilitating access to firearms by the civilian population has aroused growing interest and visibility in Brazil. This is evidenced by the recent normative changes implemented by the Executive branch and by the large number of bills in progress in the National Congress proposing to implement changes in the control of firearms in the country. In 2020, at least 14 legislatives proposals related to firearms are ready for analysis by the National Congress, with four of them dealing specifically with the possession and carrying of firearms. In total, 194 legislatives propose to change the firearms control policy in Brazil, 47 of which are expressly related to the duties of the Federal Police (National Congress, 2020).

There are two conflicting positions regarding firearms in Brazilian society, and in societies in many other countries. On the one hand, it is argued that weapons produce violence and increase the severity and lethality of banal conflicts (Thompson, Price, Dake \& Tatchell, 2006). In this perspective, weapons are directly related to the high rates of homicides and injuries. In short, firearms stimulate crime. On the other hand, it is argued that access to firearms by population would have a deterrent effect on crime due to its effectiveness as a defense tool. Thus, in this perspective, firearms would be legitimate protection instruments (Zandominighi, Martins \& Mouro, 2011). Several arguments are used to defend the two points of view. Since 2018, with the change in the federal government, access to firearms has been facilitated and even encouraged in the country. According to data from the Federal Police itself, the registrations of new firearms granted by the agency in the first six months of 2020 reached $89 \%$ of the total registrations made in 2019 . Up to June 2020 , there had been 73,985 registrations, while in all year of 2019 was 82,663.

The Disarmament Statute, created by federal law in 2003, determined Federal Police responsible for the firearms control in Brazil. The decisions related to the access to firearms by the civilian population is exclusive to the Federal Police. However, the criteria for defining who can access or carry firearms are not clear. The multiplicity of rules published and revoked in a short period of time undermines transparency and impairs monitoring the management of firearms control policy. Each revoked rule leaves a temporary vacuum in relation to its validity, which ends up giving public policy implementers the possibility to decide according to their convictions (Lima \& D'Ascenzi, 2013). Sometimes the will of the bureaucrats responsible for a specific policy becomes the most important criterion in the decision-making process (Lima \& D’Ascenzi, 2013).

In this context, the Federal Police officers become central players in the implementation of the firearms control policy in Brazil. Understanding the perception of these professionals about firearms is essential for the success of any public policy on the subject. Based on this, the objective of this research is to describe the attitude of Federal Police officers about firearms and explain this attitude based on police officers personnel experience. The data were collected through a questionnaire answered by 800 police officers, from different positions and working in all regions of the country. To measure the attitudes towards firearms we use a scale developed by Branscombe, Weir and Crosby (1991), and validated in Brazil by Nascimento, Pimentel and Adaid-Castro (2016). 


\section{LITERATURE REVIEW ON FIREARMS}

There is a large volume of empirical studies developed in the United States in recent years, establishing the country at the top of scientific production on firearms. This is explained, in part, by the high prevalence rate of weapons in the USA, the highest in the world: almost $40 \%$ of families and $22 \%$ of people own firearms (Anglemyer, Horvath \& Rutherford, 2014). Another explanation is the growing interest of American society in debating the need to tighten gun control laws, reinforced by the recent massacres in schools, universities and other public spaces (Andrés \& Hempstead, 2011; Kaufman, Morrison, Branas \& Wiebe, 2018).

In general, the reviewed studies correlate firearms with crime, indicating that an increase in the number of firearms in circulation in society tends to be accompanied by the worsening of the situation of crime and violence. The results show that the prevalence of firearms is positively related to homicide rates. Owning a firearm increases the chances of a person committing a homicide by $36 \%$ (Stroebe, 2016). Gun ownership, on the other hand, is associated with an increased risk of serious injury, accidental death and general accidents, including accidents with children (Santaella-Tenorio, Cerdá, Villaveces \& Galea, 2016; Tseng et al., 2018), and suicide (Anglemyer et al., 2014; SantaellaTenorio et al., 2016; Siegel, Ross \& King, 2013).

Box 1 presents a summary of the main studies reviewed on firearms in the scientific literature in the last ten years, with authors, place where the research was carried out, period of the research and main results.

BOX 1 SUMMARY OF REVISED STUDIES ON FIREARMS

\begin{tabular}{|c|c|c|c|}
\hline Study (Year) & $\begin{array}{l}\text { Country } \\
\text { (State/city) }\end{array}$ & $\begin{array}{l}\text { Research } \\
\text { period }\end{array}$ & Main results \\
\hline $\begin{array}{l}\text { Keil, Beardslee, } \\
\text { Schubert, Mulvey and } \\
\text { Pardini (2019) }\end{array}$ & $\begin{array}{c}\text { USA } \\
\text { (Phoenix, Arizona and } \\
\text { Pennsylvania) }\end{array}$ & $\begin{array}{l}2000 \\
\text { to } \\
2006\end{array}$ & $\begin{array}{l}\text { The availability of firearms is a significant risk } \\
\text { factor, which drives gun ownership by convicted } \\
\text { adolescent offenders. }\end{array}$ \\
\hline Hamill et al. (2019) & $\begin{array}{c}\text { USA } \\
\text { (all states) }\end{array}$ & $\begin{array}{l}1986 \\
\text { to } \\
2015\end{array}$ & $\begin{array}{l}\text { There was no significant association between the } \\
\text { legal changes implemented and the rates of violent } \\
\text { crimes and public health indicators. }\end{array}$ \\
\hline $\begin{array}{l}\text { Azrael, Cohen, Salhi } \\
\text { and Miller (2018) }\end{array}$ & $\begin{array}{c}\text { USA } \\
\text { (all states) }\end{array}$ & 2015 & $\begin{array}{l}\text { About } 7 \% \text { of US children live in homes in which at } \\
\text { least one firearm, loaded and unlocked, is stored. } \\
\text { This is more than double the proportion seen in } \\
2002 \text {, reflecting the belief that a gun makes the } \\
\text { home safer. }\end{array}$ \\
\hline Crifasi et al. (2018) & $\begin{array}{c}\text { USA } \\
\text { (136 urban municipalities) }\end{array}$ & $\begin{array}{l}1984 \\
\text { to } \\
2015\end{array}$ & $\begin{array}{l}\text { Strict firearms control laws have been linked to a } \\
14 \% \text { reduction in firearm homicide rates in large } \\
\text { urban centers. }\end{array}$ \\
\hline
\end{tabular}


RAP | The attitude of Brazilian federal police officers towards firearms

\begin{tabular}{|c|c|c|c|}
\hline Study (Year) & $\begin{array}{l}\text { Country } \\
\text { (State/city) }\end{array}$ & $\begin{array}{l}\text { Research } \\
\text { period }\end{array}$ & Main results \\
\hline $\begin{array}{l}\text { Manley, Fabian, } \\
\text { Sharpe, Magnotti and } \\
\text { Croce (2018) }\end{array}$ & $\begin{array}{c}\text { USA } \\
\text { (Memphis, Tenesse) }\end{array}$ & $\begin{array}{l}1996 \\
\text { to } \\
2016\end{array}$ & $\begin{array}{l}\text { The mortality rate from firearm injuries decreased } \\
\text { during the survey period, but the number of multi- } \\
\text { compartment injuries increased. }\end{array}$ \\
\hline Tseng et al. (2018) & $\begin{array}{c}\text { USA } \\
\text { (all states) }\end{array}$ & $\begin{array}{l}2000 \\
\text { to } \\
2009\end{array}$ & $\begin{array}{l}\text { Accidents with firearms were inversely related to } \\
\text { age. White people were the most likely to have } \\
\text { accidental injuries, while blacks and Hispanics, } \\
\text { injuries resulting from aggression. }\end{array}$ \\
\hline Diez et al. (2017) & $\begin{array}{c}\text { USA } \\
\text { (all states) }\end{array}$ & $\begin{array}{l}1991 \\
\text { to } \\
2015\end{array}$ & $\begin{array}{l}\text { States that have adopted laws that prohibit } \\
\text { individuals accused of domestic violence from } \\
\text { acquiring/owning firearms had lower homicide } \\
\text { rates than those that did not. }\end{array}$ \\
\hline $\begin{array}{l}\text { Kalesan and Galea } \\
\text { (2017) }\end{array}$ & $\begin{array}{c}\text { USA } \\
\text { (all states) }\end{array}$ & $\begin{array}{l}1999 \\
\text { to } \\
2013\end{array}$ & $\begin{array}{l}\text { In general, homicide rates were significantly } \\
\text { associated with firearms possession, although } \\
\text { there are wide differences in firearm mortality rates } \\
\text { across US states. }\end{array}$ \\
\hline Malta et al. (2017) & $\begin{array}{c}\text { Brazil } \\
\text { (all states) }\end{array}$ & $\begin{array}{l}1990 \\
\text { to } \\
2015\end{array}$ & $\begin{array}{l}\text { Among the external causes of mortality, attacks } \\
\text { by firearms predominated, followed by transport } \\
\text { accidents. }\end{array}$ \\
\hline $\begin{array}{l}\text { Ribeiro, Souza and } \\
\text { Sousa (2017) }\end{array}$ & $\begin{array}{l}\text { Brazil } \\
\text { (24 state capitals and the } \\
\text { Federal District) }\end{array}$ & 2014 & $\begin{array}{l}\text { Injuries caused by firearms treated in Brazilian } \\
\text { urgency and emergency services in } 2014 \\
\text { represented } 65.1 \% \text { of the total number of cases. }\end{array}$ \\
\hline $\begin{array}{l}\text { Paper, Oliveira, Federal } \\
\text { and Grande (2017) }\end{array}$ & $\begin{array}{c}\text { Brazil } \\
\text { (33 municipalities in the } \\
\text { administrative region of Porto } \\
\text { Alegre - RS) }\end{array}$ & $\begin{array}{l}2007 \\
\text { to } \\
2013\end{array}$ & $\begin{array}{l}\text { There is a positive and statistically significant } \\
\text { relationship between the availability of firearms and } \\
\text { homicides with firearms in the region. }\end{array}$ \\
\hline $\begin{array}{l}\text { Maciel, Souza and } \\
\text { Rosso (2016) }\end{array}$ & $\begin{array}{c}\text { Brazil } \\
\text { (Goiânia - GO) }\end{array}$ & $\begin{array}{l}\text { 01/2013 to } \\
03 / 2013\end{array}$ & $\begin{array}{l}\text { The majority of victims of firearm are young men, } \\
\text { alcohol and/or drug users; most of whom are } \\
\text { involved in drug trafficking. }\end{array}$ \\
\hline $\begin{array}{l}\text { Santaella-Tenorio et al. } \\
\text { (2016) }\end{array}$ & $\begin{array}{l}\text { South Africa, Australia, } \\
\text { Austria, Brazil, Canada, USA, } \\
\text { New Zealand, Switzerland } \\
\text { (Meta analysis) }\end{array}$ & $\begin{array}{l}1950 \\
\text { to } \\
2014\end{array}$ & $\begin{array}{l}\text { Evidence from } 130 \text { studies suggests that the } \\
\text { implementation of restrictive firearms possession } \\
\text { laws is associated with a) reductions in homicides } \\
\text { with guns, b) reductions in homicide rates } \\
\text { committed by intimate partners, and c) in accidents } \\
\text { with firearms. }\end{array}$ \\
\hline $\begin{array}{l}\text { Swedler, Simmons, } \\
\text { Dominici and } \\
\text { Hemenway (2015) }\end{array}$ & $\begin{array}{c}\text { USA } \\
\text { (all states) }\end{array}$ & $\begin{array}{l}1996 \\
\text { to } \\
2010\end{array}$ & $\begin{array}{l}\text { More than } 90 \% \text { of police homicides in the USA are } \\
\text { committed with firearms. Police homicide rates } \\
\text { were three times higher in states with high gun } \\
\text { ownership rates. }\end{array}$ \\
\hline
\end{tabular}




\begin{tabular}{|c|c|c|c|}
\hline Study (Year) & $\begin{array}{l}\text { Country } \\
\text { (State/city) }\end{array}$ & $\begin{array}{l}\text { Research } \\
\text { period }\end{array}$ & Main results \\
\hline Anglemyer et al. (2014) & $\begin{array}{c}\text { USA } \\
\text { (16 states) }\end{array}$ & 2009 & $\begin{array}{l}\text { Access to firearms is associated with an increased } \\
\text { risk of committing suicide, or of becoming a victim } \\
\text { of homicide. }\end{array}$ \\
\hline Siegel et al. (2014) & $\begin{array}{c}\text { USA } \\
\text { (all states) }\end{array}$ & $\begin{array}{l}1981 \\
\text { to } \\
2010\end{array}$ & $\begin{array}{l}\text { No statistically significant correlation was found } \\
\text { between possession of firearms and homicide rates } \\
\text { for firearms committed against outsiders. However, } \\
\text { there was a positive and significant association } \\
\text { between possession and homicides committed } \\
\text { against people in the inner circle. }\end{array}$ \\
\hline Siegel et al. (2013) & $\begin{array}{c}\text { USA } \\
\text { (all states) }\end{array}$ & $\begin{array}{l}1981 \\
\text { to } \\
2010\end{array}$ & $\begin{array}{l}\text { States with high rates of firearm possession have } \\
\text { more homicides related to firearms. For each } \\
\text { percentage point increase in firearms possession, } \\
\text { the firearm homicide rate increased by } 0.9 \% \text {. }\end{array}$ \\
\hline $\begin{array}{l}\text { Todeschini, Veiga, } \\
\text { Souza, Saade and } \\
\text { Aguiar (2013) }\end{array}$ & $\begin{array}{c}\text { Brazil } \\
\text { (São Paulo - SP) }\end{array}$ & $\begin{array}{l}1991 \\
\text { to } \\
2005\end{array}$ & $\begin{array}{l}85 \% \text { of firearm victims were male, with an average } \\
\text { age of } 31 \text { years. }\end{array}$ \\
\hline Mello-Silva et al. (2012) & $\begin{array}{c}\text { Brazil } \\
\text { (Goiânia - G0) }\end{array}$ & 2007 & $\begin{array}{l}\text { The analysis of } 95 \text { victims of interpersonal violence } \\
\text { by firearms at the main reference hospital for } \\
\text { emergency care identified post-traumatic stress } \\
\text { disorders in } 60 \% \text { of cases. }\end{array}$ \\
\hline
\end{tabular}

Source: Elaborated by the authors based on the literature review.

Another finding is that the increased availability of firearms is directly related to the increase in domestic violence. The results indicate that the presence of firearms considerably increases the severity of interpersonal conflicts and violence committed within the intimate circle (Diez et al., 2017; Ribeiro et al., 2017; Siegel et al., 2014). Several studies (Branscombe et al., 1991; Caneda \& Teodoro, 2010; Maciel et al., 2016; Malta, 2017; Nascimento et al., 2016; Sanches, Duarte \& Pontes, 2009; Todeschini, 2013; Trindade, 2015; Tseng, 2018; Zandominighi et al., 2011) investigated the distribution of violence between genders, indicating an absolute prevalence of males, usually young, under the age of 30 . What the results indicate is that two factors in particular, sex and age, have great potential to influence people's perception of firearms.

Regarding police behavior, some interesting results are worth mentioning. The length of service of the police officer, for example, appears to be a relevant factor in the perception of firearms. More experienced policemen tend to adopt a more favorable attitude towards controlling the circulation of weapons when compared to less experienced policemen (Thompson et al., 2006). Among American police officers, being a member of the National Rifle Association (NRA), the most powerful pro-gun association in the United States, is a factor in influencing the perception of firearms. Associated police officers are less supportive of gun control measures (Thompson et al., 2006). 
Part of the empirical studies reviewed (Costa, Njaine \& Schenker, 2017; Domingues \& Dessen, 2013; Domingues, Villas Boas \& Dessen, 2011; Mello-Silva et al., 2012) addressed topics related to the impact of violence on the victims' quality of life, including the policemen. One of the most addressed topics concerns the symptoms of post-traumatic stress triggered by physical disabilities and losses suffered. This approach suggests that victimization and exposure to episodes of gun violence can leave psychological scars, and that these scars can be to a greater or lesser extent and predict future perceptions about firearms.

\subsection{Measuring firearms perception}

We provide another literature review aimed to map the scales available in the literature to measure people's perception of firearms. In total, we found six studies, the oldest published in 1991 and the most recent in 2019. The selected studies and the scales used are presented in the following paragraphs.

One of the first scales to measure perception about firearms was created by Branscombe, Weir and Crosby (1991). The scale, called Attitudes Toward Guns Scale (ATGS), was created and applied initially in the United States and considers three dimensions related to firearms: right, crime and protection. The first factor involves an abstract set of beliefs about the right of the American population to own firearms; the second factor assesses the extent to which people believe that firearms stimulate crime; and the third factor assesses whether people believe that possession of firearms offers protection against crime. The questionnaire containing 59 items was applied to a group of American university students, with 108 men and 168 women. The retention of items with a factor load greater than 0.50 resulted in the final version of the scale, consisting of 17 items (Branscombe et al., 1991). Regression analysis indicated that the 'right' subscale is uniquely predicted by political identification, self-esteem, and pride in American identity. The notion that guns provide personal 'protection' from crime is predicted by politically conservative, persons less optimistic, and high in distrust of others. And the sole significant predictor of the crime subscale was political orientation, more conservative persons tended to disagree most that guns cause crime (Branscombe et al., 1991).

Another scale was developed by Keinert, Fonseca, Blikstein, Storino and Sano (2005) to investigate the values and meanings attributed to firearms by their owners. The scale was applied in 2005 through 6,000 questionnaires sent to firearm owners who lived in municipalities in seven Brazilian states: Espírito Santo, Mato Grosso, Pernambuco, Rio de Janeiro, Rondônia, Rio Grande do Sul and São Paulo. The specific objective of the research was to test the hypothesis of a correlation between the possession of firearms and the level of violence perceived by the owners. The questionnaire contained 37 questions separated into four blocks, almost all of which were multiple choice. The questionnaire responses indicated that the perception of violence was statistically correlated with the acquisition of firearms (Keinert et al., 2005).

The perception of United States police chiefs regarding firearms was investigated by Thompson et al. (2006). The authors developed a scale with 29 items that was sent by email to a random sample of 600 police chiefs in cities with populations greater than 25,000 inhabitants. The results indicate that the majority of participants supported firearms control policies. Respondents believed that the 
government should do everything possible to keep weapons out of the hands of criminals, even if it makes it more difficult for ordinary citizens to acquire firearms. According to the authors, the respondents' perception differs according to the length of service in the police and the fact that they are associated with the National Rifle Association (NRA) (Thompson et al., 2006).

A scale called the Weapon Motivation Scale (WMS) was used by Caneda and Teodoro (2010) to identify the motivation for the use of civilian and military weapons in the Brazilian state of Rio Grande do Sul. The scale was applied to 550 respondents, 258 of whom men and 292 women, aged 18 to 86 years. The final version of the scale had 36 items, distributed in four factors: protection, risk, right/tradition, and exposure, which together explained $48 \%$ of the total variance. The findings indicated that men, when compared to women, showed more favorable attitudes regarding firearms, presenting a higher score in two factors: protection and right. According to the authors, this means that men are more likely to perceive firearms as an instrument of protection against crime, and that possession of firearms is an individual right (Caneda \& Teodoro, 2010).

Another study in Brazil, this time using the Attitudes Toward Guns Scale (ATGS), developed by Branscombe et al. (1991), was conducted by Nascimento et al. (2016). Initially, the scale was applied to 200 military police officers from the Federal District Military Police, chosen non-randomly, of which $87.5 \%$ were male. The analysis of the main components indicated a tri-factor structure, as in the study of origin, with Cronbach's alpha of 0.81 for 'right', 0.76 for 'protection' and 0.65 for 'crime'. In the second stage of the study, a confirmatory study was carried out to check the adequacy of the scale, with a sample of 220 university students chosen non-randomly, of which 53\% were female. Confirmatory factor analysis also confirmed the tri-factor structure. Men had the highest mean for the 'right' and 'protection' factors. Women, on the other hand, the highest mean for the 'crime' factor. The parameters did not vary significantly based on age (Nascimento et al., 2016).

A recent study was developed by Wombacher and Wallace (2019) to examine the effects of socialization with firearms in childhood on attitudes related to firearms in adulthood. The study addresses age, the source of initial exposure (parents, siblings, relatives) and perceptions of experiences with firearms during childhood. The research was carried out with a sample of 298 students from Americans universities through an electronic questionnaire composed of 95 items. The results indicate that 'pro-gun' attitudes in adulthood are associated with childhood exposure, as well as the fact that the weapon belongs to someone close, such as relatives and friends. However, experiences with firearms in childhood were not shown to be related to adult attitudes (Wombacher \& Wallace, 2018).

Other studies have also carried out research with police officers, testing the adequacy of psychometric scales, however, the focus of analysis of these studies is different and they do not deal directly with firearms. Example is the study of Nascimento, Souza and Adaid-Castro (2020), that evaluated the psychometric adequacy of the Professional Competencies for Police Officers Scale (PCPOS), which focused on the 'behavioral' and 'technical' skills of police officers (Nascimento et al., 2020). 


\section{DATA AND RESEARCH DESIGN}

The study was conducted with police officers from the Brazilian Federal Police (FP). The FP has the objective of investigating crimes and criminal offenses committed against the Estate and its public companies. The FP exercises, exclusively, the functions of the judicial police, that is, it investigates crimes and collects evidence that will be used in Federal Justice. The FP is subordinate to the Ministry of Justice. FP's headquarters are in Brasília, but the institution has units in all states of the country. There are 95 decentralized FP stations in cities considered strategic, such as large urban centers and borders. In November 2019, the FP had 10,732 active police officers, including delegates, agents, clerks, experts and papiloscopists.

The data were collected through an electronic questionnaire sent by the FP Social Communication Division directly to the functional e-mail of all active police officers. Accompanying the access link to the research instrument was a presentation letter containing information about the proposed objectives and the commitment to the confidentiality of the information, emphasizing that they would be used for strictly academic purposes. The study sample consisted of 800 police officers, divided into five positions: agents (50.3\%), delegates (24.6\%), clerks (11\%), experts (10\%) and papiloscopists (4.1\%). The study sample represents $7.5 \%$ of the total of police officers working in the FP in November 2019. Table 1 shows a comparison between FP positions in the population and in the study sample.

TABLE 1 COMPARISON BETWEEN FP POSITIONS IN THE POPULATION AND IN THE STUDY SAMPLE

\begin{tabular}{lccccc}
\hline FP positions & Total & $\%$ & Respondents & $\%$ & \% by position \\
\hline Agent & 5.854 & 54,5 & 402 & 50,3 & 6,9 \\
Delegate & 1.552 & 14,5 & 197 & 24,6 & 12,7 \\
Clerk & 1.793 & 16,7 & 88 & 11,0 & 4,9 \\
Expert & 1.081 & 10,1 & 80 & 10,0 & 7,4 \\
Papiloscopist & 452 & 4,2 & 33 & 4,1 & 7,3 \\
\hline
\end{tabular}

Source: Elaborated by the authors using information from the Federal Police Personnel Management Department.

Male police officers predominated in the sample (90.1\%), which closely reflects the distribution of genders in the number of FP officers. Regarding the age of the respondents, there was a wide variation, ranging from less than 30 to more than 60 years of age, with $27.3 \%$ of the sample consisting of people aged between 41 and 45 years. $66.2 \%$ of respondents are married, $69.2 \%$ are white, $44.8 \%$ are Catholic and $22.1 \%$ declare themselves to be atheists or agnostics. Regarding the number of children, $33.2 \%$ of the participants have two children, and $30.8 \%$ have no children. As for the length of activity in the Federal Police, there was also a wide range, ranging from 1 to 42 years, with an average of 13.8 years, also equivalent to the distribution in the studied population. $50.7 \%$ of the participants have an undergraduate degree, and $38.6 \%$ have a graduate degree. 
The questionnaire was divided into three blocks. The first block contains the scale. Among the available scales of firearms, we consider that the most suitable for the purposes of this study is the Attitudes Toward Guns Scale (ATGS), developed by Branscombe et al. (1991), and initially tested in Brazil by Nascimento et al. (2016). The ATGS is composed of 17 items (see Table 3) covering three factors related to firearms: right - right to own firearms; protection - protection that weapons offer against crimes; and crime - stimulus that firearms generate in crime. The items were evaluated using a Likert scale, with 8 points, where 1 represent the lowest disagreement, and 8 the highest agreement.

The second block deal with the police officers experience and the police experience about firearms. To operationalize the police experience, the first variable is the time, in years, that the respondent works as a police officer in the FP. Another variable consists of the respondent's position, operationalized by four dichotomous variables: delegate, clerk, expert and papiloscopist (agents' position was used as baseline). To operationalize the police officers' experience with firearms, we use six variables: i) the age in which the respondent had the first contact with firearms, ranging from 1 to 8,1 being less than ten years old, and 8 being more than 40 years old; ii) the number of firearms that the respondent has, in units; iii) the frequency of possession and iv) frequency of use of firearms, both varying from 1 to 6,1 for very low frequency and 6 for very high frequency; and v) having suffered or vi) witnessed injury caused by a firearm, both dichotomous.

Finally, the third block of the questionnaire consists of the following demographic variables: i) age group - 1 to 8 ; 1 being less than 30 years old and 8 over 60 years old; ii) gender - 1 male and 0 female; iii) marital status - 1 married and 0 not married; iv) child - 1 child and 0 no child; v) skin color - 1 white and 0 other colors; vi) educational background - 1 to $6 ; 1$ with a medium level and 6 with a doctorate; and vii) degree of religiosity - 0 to 5; 0 being nothing religious and 5 very religious.

The descriptive statistics of the variables are shown in Table 2. Based only on the averages is it possible to say that the police officers interviewed consider that possession of firearms is a right (5.16) and that weapons do not represent protection against crime (3.19). The crime factor average (3.93) is very close to the midpoint of the scale (4.5). It is important to note that this analysis based on the average is very limited and should be viewed with caution, since it considers the aggregate of the perceptions of the different positions of the respondents.

\section{TABLE 2 DESCRIPTIVE STATISTICS}

$\begin{array}{llccc}\text { Variables } & \text { Mean } & \text { S.d. } & \text { Min } & \text { Max } \\ \text { Scale factors } & & & 1 & 8 \\ \text { Right (1-8; average items) } & 5.16 & 1.89 & 1.76 & 8 \\ \text { Crime (1-8; average items) } & 3.93 & 1.51 & 1 & 8 \\ \text { Protection (1-8; average items) } & 3.19 & & 1 & 42 \\ \text { Police experience } & & 7.07 & & \text { Continue } \\ \text { Experience as a Federal Police officer (years) } & 13.77 & & \end{array}$




\begin{tabular}{|c|c|c|c|c|}
\hline Variables & Mean & S.d. & Min & Max \\
\hline Delegate position (d) & .25 & .43 & 0 & 1 \\
\hline Agent (d) & .48 & .500 & 0 & 1 \\
\hline Clerk (d) & .11 & .313 & 0 & 1 \\
\hline Papiloscopist (d) & .10 & .300 & 0 & 1 \\
\hline Expert (d) & .04 & .199 & 0 & 1 \\
\hline \multicolumn{5}{|l|}{ Experience with firearms } \\
\hline Age range of initial firearm contact (1-8) & 3.70 & 1.63 & 1 & 8 \\
\hline Number of firearms of possession & 1.19 & 1.52 & 0 & 7 \\
\hline Frequency of carrying firearms (1-6) & 4.00 & 1.13 & 1 & 5 \\
\hline Shooting frequency (1-6) & 2.25 & .87 & 1 & 6 \\
\hline Suffered injury caused by firearms (d) & .03 & .18 & 0 & 1 \\
\hline Witnessed firearms injury (d) & .13 & .34 & 0 & 1 \\
\hline \multicolumn{5}{|l|}{ Demographic } \\
\hline Age range (1-8) & 4.12 & 1.57 & 1 & 8 \\
\hline Male (d) & .90 & .29 & 0 & 1 \\
\hline Married (d) & .79 & .41 & 0 & 1 \\
\hline Child (d) & .69 & .46 & 0 & 1 \\
\hline White (d) & .69 & .46 & 0 & 1 \\
\hline Education background (1-6) & 2.62 & .73 & 2 & 6 \\
\hline Religiosity (0-5) & 2.36 & 1.63 & 0 & 5 \\
\hline
\end{tabular}

Source: Elaborated by the authors; N: 800 .

We run confirmatory factorial analysis (CFA) to verify the model convergent validity, that is, the coherence between the indicators and between the construct, and the model discriminant validity, that is, if the model variables measure different constructs from each other (Byrne, 2010). Also, we run a second-order CFA model with the three factors (right, protection, and crime) loading on a higher-order latent variable called 'general attitude towards firearms.'

To explain the general attitude towards firearms of the interviewees, we run linear regression. To operationalize the dependent variables, we use the predicted factor scores of each of the three factors. Also, we use the predicted factor scores of that CFA second-order latent variable to form the 'general attitude towards firearms' variable. Thus, four different regression models were estimated. The independent variables consist of the respondents' experience in the FP and they experience with firearms (see the variables presented in Table 2). We use demographic variables of police officers as control, such as age, sex and education. The choice for regression after CFA is due to the fact that the independent variables are not continuous, which makes it impossible for them to be included in the models estimated in the CFA. 


\section{RESULTS AND DISCUSSION}

In the confirmatory factor analysis (CFA), the one-dimensional measurement model (Model 1) was initially tested, as suggested by Byrne (2016). The adjustments were not satisfactory (CMIN/DF=9.96; GFI=0.83; CFI=0.66; RMSEA=0.10), which indicated the need for multidimensional models. With that, the first order CFA (Model 2) was conducted with the three expected latent variables (right, crime and protection). All estimates were statistically significant ( $\mathrm{p}$-value $<0.001)$. However, the correlations between latent variables were high (correlation between right and crime: -0.85 ; right and protection: 0.78; and crime and protection: -0.70 ). This indicates the possibility of the constructs together forming another broader dimension, which was tested by conducting the second order CFA (Model 3). The estimates are shown in Table 3.

\section{TABLE 3 SECOND ORDER CFA ESTIMATES (MODEL 3)}

\begin{tabular}{|c|c|c|c|c|c|c|}
\hline & & & Estimate & S.E. & C.R. & $\begin{array}{c}\text { Standardized } \\
\text { regression } \\
\text { weights }\end{array}$ \\
\hline Right & $<---$ & General attitude & 1.000 & & & $.969^{\star \star \star}$ \\
\hline Crime & $<---$ & General attitude & -.692 & .039 & -17.811 & $-.876^{\star \star \star}$ \\
\hline Protection & $<---$ & General attitude & .704 & .040 & 17.479 & $.804^{\star \star \star}$ \\
\hline Item_R7 & $<---$ & Right & 1.000 & & & $.829^{\star \star \star}$ \\
\hline Item_R6 & $<---$ & Right & .749 & .034 & 22.295 & $.704^{\star \star \star}$ \\
\hline Item_R5 & $<---$ & Right & 1.016 & .037 & 27.618 & $.819^{\star \star \star}$ \\
\hline Item_R4 & $<---$ & Right & 1.029 & .035 & 29.622 & $.855^{\star \star \star}$ \\
\hline Item_R3 & $<---$ & Right & .791 & .037 & 21.509 & $.685^{\star \star \star}$ \\
\hline Item_R2 & $<---$ & Right & .837 & .031 & 27.226 & $.804^{\star \star \star}$ \\
\hline Item_R1 & $<---$ & Right & 1.024 & .038 & 27.012 & $.801^{\star \star \star}$ \\
\hline Item_C5 & $<---$ & Crime & 1.000 & & & $.713^{\star \star \star}$ \\
\hline Item_C4 & $<---$ & Crime & 1.302 & .056 & 23.077 & $.873^{\star \star \star}$ \\
\hline Item_C3 & $<---$ & Crime & 1.086 & .052 & 21.010 & $.783^{\star \star \star}$ \\
\hline Item_C2 & $<---$ & Crime & .830 & .049 & 16.960 & $.627^{\star \star \star}$ \\
\hline Item_C1 & $<---$ & Crime & 1.193 & .060 & 19.768 & $.740^{\star \star \star}$ \\
\hline Item_P4 & $<---$ & Protection & 1.000 & & & $.754^{\star \star \star}$ \\
\hline Item_P3 & $<---$ & Protection & .422 & .027 & 15.607 & $.583^{\star \star \star}$ \\
\hline & \multicolumn{2}{|c|}{ Right } & \multicolumn{2}{|c|}{ Crime } & \multicolumn{2}{|r|}{ Protection } \\
\hline Jöreskog Rho & \multicolumn{2}{|c|}{0.91} & \multicolumn{2}{|c|}{0.86} & \multicolumn{2}{|r|}{0.82} \\
\hline AVE & \multicolumn{2}{|c|}{0.62} & \multicolumn{2}{|c|}{0.56} & & 0.53 \\
\hline
\end{tabular}

$* * *$ p-value $<0.001$

Source: Elaborated by the authors. 
The convergent validity of the latent variables was analyzed. For this, the standardized parameters of the regression $(>0.5)$, the extracted average variance (AVE $\geq 0.5$ ), and Jöreskog's Rho $(>0.7)$ were verified (Hair, Anderson, Tatham \& Black, 2009). Table 3 shows that the regression estimates for all items were greater than 0.5. In addition, the AVE and Jöreskog Rho values were adequate. Thus, convergent validity has been confirmed.

Figure 2 shows the second order CFA model. The second order latent variable 'general attitude' is explained by the three factors. The relationship between right and protection with the general attitude is positive, while the relationship between crime and general attitude is negative. This means that a positive attitude towards firearms involves believing that possession of firearms is a right; that firearms protect against crime; and that firearms do not stimulate the crime.

FIGURE 1 SECOND-ORDER CFA MODEL

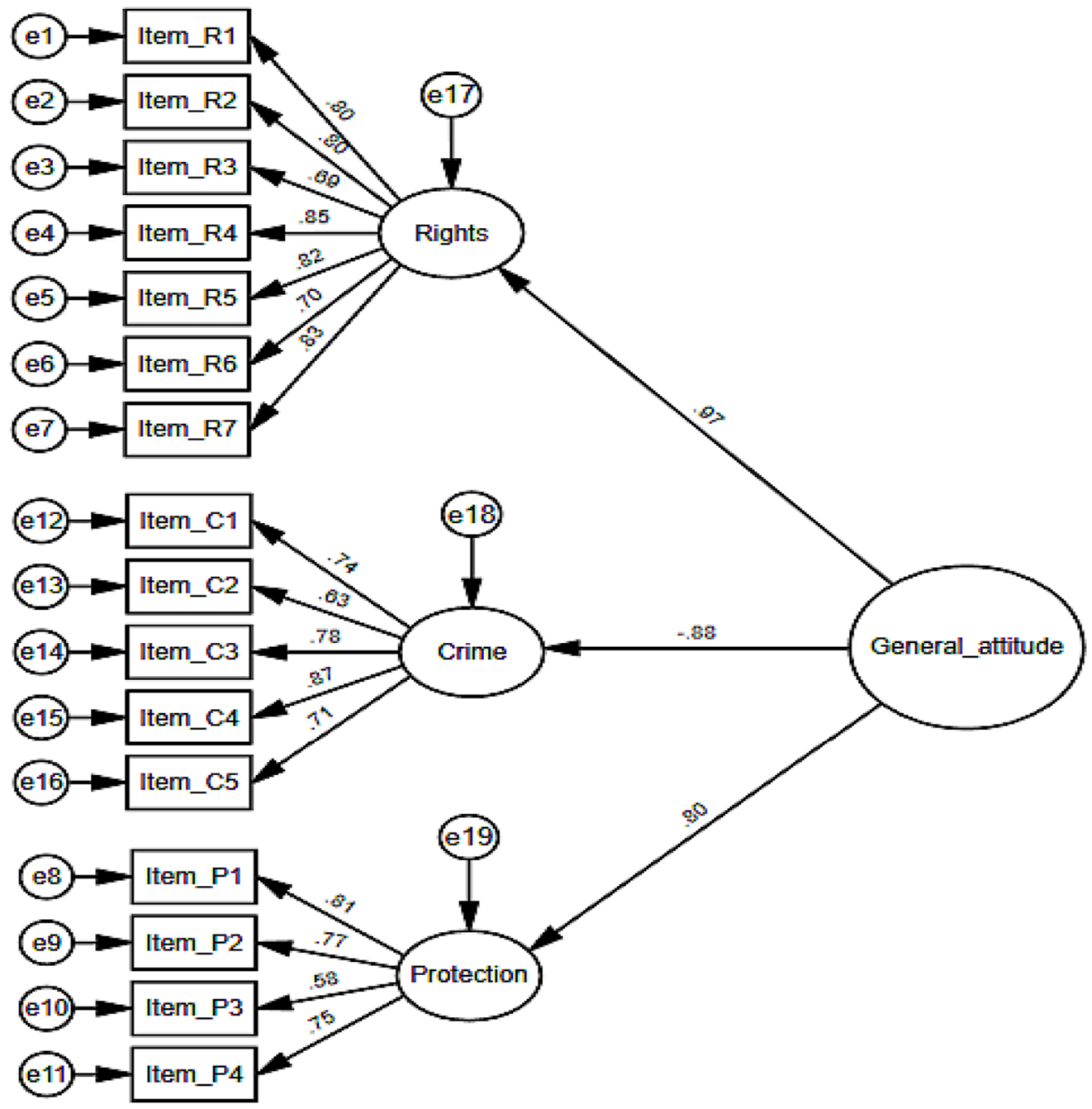

Source: Elaborated by the authors 
The adjustment measures of the models were analyzed and compared. The Goodness of Fit Index (GFI) and the Comparative Fit Index (CFI) indices present values between zero and one, and the closer to one, the greater the model fit adequacy indicator. The Root Mean Square Error of Approximation (RMSEA) points to an adequate adjustment model when it has a value less than 0.1 (Marôco, 2010). As a final precaution, Byrne (2010) recommends that the ratio between chi-square and degrees of freedom does not exceed 5. Table 4 compares the three measurement models tested. According to the goodness of fit indices presented, models 2 and 3 have very similar results and both can be considered adequate.

\section{TABLE 4 COMPARISON BETWEEN THE ADJUSTMENT INDEXES OF MODELS 1, 2 AND 3}

\begin{tabular}{lccc} 
Adjustment indices & $\begin{array}{c}\text { Model 1 } \\
\text { (one-dimensional) }\end{array}$ & $\begin{array}{c}\text { Model 2 } \\
\text { (first order) }\end{array}$ & $\begin{array}{c}\text { Model 3 } \\
\text { (second order) }\end{array}$ \\
\hline CMIN/DF & 9.96 & 3.61 & 3.61 \\
GFI (AGFI) & $0.83(0.78)$ & $0.94(0.92)$ & $0.94(0.92)$ \\
CFI & 0.66 & 0.94 & 0.96 \\
RMSEA & 0.10 & 0.06 & 0.06
\end{tabular}

Source: Elaborated by the authors

A second stage of the analyzes sought to explain the respondents' attitude towards firearms. As reported, the dependent variables consist of the predicted factor scores of the three factors of the scale and the resultant variable of the second order CFA, which we call the general attitude. Thus, four different regression models were estimated. The regression results are shown in Table 5.

\section{TABLE 5 REGRESSION RESULTS FOR GENERAL ATTITUDE TOWARDS FIREARMS}

\begin{tabular}{lcccc} 
& \multicolumn{3}{c}{ Dependent variables } \\
Independent variables & Rigths & Crime & Protection & General attitude \\
Police experience & & & & -058 \\
Experience in FP & -.062 & .029 & -.039 & $-.055^{\star *}$ \\
Delegate & $-.132^{\star *}$ & $.134^{\star *}$ & $-.128^{\star *}$ & -.047 \\
Clerk & -.031 & -.011 & -.016 & -.043 \\
Papiloscopist & -.050 & .051 & -.058 & -.038 \\
Expert & -.019 & .008 & -.040 & Continue
\end{tabular}




\begin{tabular}{|c|c|c|c|c|}
\hline \multirow{2}{*}{ Independent variables } & \multicolumn{4}{|c|}{ Dependent variables } \\
\hline & Rigths & Crime & Protection & General attitude \\
\hline \multicolumn{5}{|l|}{ Firearms experience } \\
\hline Initial contact with firearm & $-.155^{\star \star}$ & $.148^{\star \star}$ & $-.119^{\star \star}$ & $-.099^{\star \star}$ \\
\hline Num. of firearms in possession & $.198^{\star \star}$ & $-.136^{\star \star}$ & $.128^{\star \star}$ & $.151^{\star \star}$ \\
\hline Frequency of carrying & $.157^{\star \star}$ & $-.166^{\star \star}$ & $.136^{\star \star}$ & $.098^{\star \star}$ \\
\hline Shooting frequency & $-.110^{\star \star}$ & $.152^{\star \star}$ & $-.106^{\star \star}$ & $-.047^{*}$ \\
\hline Suffered injury & .058 & -.034 & .028 & .042 \\
\hline Witnessed injury & -.036 & $.064^{\star}$ & -.039 & -.006 \\
\hline \multicolumn{5}{|l|}{ Individual atributes } \\
\hline Age & .020 & .005 & $.114^{\star}$ & $.101^{*}$ \\
\hline Male & .014 & .034 & -.018 & .027 \\
\hline Married & .057 & -.012 & -.017 & .028 \\
\hline Child & .035 & -.025 & -.036 & -.015 \\
\hline White & .038 & -.027 & -.017 & .000 \\
\hline Education background & -.001 & -.011 & -.018 & -.023 \\
\hline Religiosity & $.103^{\star \star}$ & -.103 & $.133^{\star \star}$ & $.099^{\star \star}$ \\
\hline Constant & $4.193^{\star \star}$ & $3.891^{* *}$ & $3.034^{\star *}$ & $3.906^{\star \star}$ \\
\hline Anova (F) & $13.330^{\star \star}$ & $11.089^{\star \star}$ & $8.650^{\star \star}$ & $12.424^{\star \star}$ \\
\hline $\mathrm{R}^{2}$ & .235 & .203 & .166 & .222 \\
\hline
\end{tabular}

Source: Elaborated by the authors; $\mathrm{N}=766 ;{ }^{*} p<0.05 ;{ }^{* *} p<0.01$.

The police officers' attitude towards firearms is explained by their position in the FP and their experience with firearms. The police officers' experience plays an important role in explaining their perception about firearms. Almost all experience variables proved to be statistically significant. On the one hand, the quantity of firearms and the frequency with which the police officer carry his firearm positively affect the general attitude. In other words, the more firearms the respondent has, and the more frequent the firearms use are, the more likely the police officer are to have a positive attitude towards firearms.

On the other hand, the position of delegate, the initial contact with firearms, and the frequency of firing negatively affect the general attitude of the respondents. This means that delegates, compared to respondents who occupy other positions in the FP, are less likely to show a positive attitude towards firearms. Also, the police officers who had initial contact with firearms and the police officers who use their weapons more frequently are less likely to have a positive attitude towards firearms.

The fact that delegates have a less positive general attitude towards firearms may reflect their great responsibility towards the country's arms control policy. It is the delegate who decides to grant the possession of arms; he is responsible for approving or denying citizens access to carrying firearms, 
as provided in the Disarmament Statute. Thus, the weight of this responsibility for the delegate, and the consequences arising from the granting of possession, can influence his attitude towards firearms. This result is in line with the findings by Thompson et al. (2006), in a study conducted with police chiefs in the United States. The findings showed that the vast majority of investigated police chiefs considered that firearms stimulate crime, and therefore should be restricted as much as possible to the civilian population through a strict public control policy.

It is interesting to note the difference in results in relation to the possession and use of firearms. Police officers who claimed to have more firearms, and who carry their firearms more often, showed a more positive general attitude towards firearms. Conversely, those who claimed to use firearms more often, on the contrary, had a less positive overall attitude. This may mean that the effective use of firearms tends to reduce the idealization that is often nurtured in relation to firearms. In other words, the frequency of use of firearms seems to encourage greater responsibility and critical sense by the police in relation to the dangers associated with guns.

Note that the respondent's experience as a police officer and the fact of having suffered or witnessed injury caused by a firearm did not have significant effects on the dependent variables. That is, neither time in the profession nor negative experiences tend to influence respondents' opinions about firearms. Regarding the experience as a police officer, this result is different from the findings of other previous studies (Branscombe et al., 1991; Caneda \& Teodoro, 2010; Cerqueira, 2014; Fowler, 2015; Maciel et al., 2016; Malta, 2017; Nascimento et al., 2016; Todeschini, 2013; Trindade, 2015; Tseng, 2018; Sanches et al., 2009; Zandominighi et al., 2011). In the case of negative experiences, one possible explanation is that the rigid training that police officers receive from the Federal Police conditions them to accept the risks associated with the profession, including the risk of being shot.

Among the control variables used in the models, only the degree of religiosity was statistically significant, the other control variables failed to explain the respondent's perceptions about firearms. Thus, it can be said that the more religious, the greater the propensity of police officers to present a positive attitude towards firearms. In other words, respondents' opinions about firearms depend less on their personal characteristics, such as age, sex, race, family and education, and more on their religious beliefs. The findings on the influence of the respondents' degree of religiosity seem to converge with some findings in the literature, especially from the study by Prandi and Santos (2017). These authors showed that Brazilians take different positions according to their religious affiliation on issues related to the behavior and morals that guide them. The present research also provides evidence for this phenomenon among police officers, indicating that their views on firearms are shaped by the religious beliefs they adopt.

The results did not indicate that female police officers, when compared to male, has a different perception of firearms. This result is different from the findings of several previous studies (Branscombe et al., 1991; Caneda \& Teodoro, 2010; Fowler, 2015; Maciel et al., 2016; Malta, 2017; Nascimento et al., 2016; Sanches et al., 2009; Shapiro, Dorman, Burkes, Welker \& Clough, 1997; Todeschini, 2013; Trindade, 2015; Tseng, 2018; Zandominighi et al., 2011). The interpretation of this result may lie in the need for constant possession of a firearm by Federal Police officers. In this case, traditional gender representations are not sustained, or are attenuated to the point that they have no relevant influence. 
The study presents practical contributions for Federal Police managers, as it provides important information for the development of management strategies and practices aimed at prevention and psychological support for police officers regarding the use of firearms. Understanding that the perception of delegates regarding firearms is different from the perception of police officers who occupy other positions in the FP is important for the institution to define specific training and psychological development strategies. It can also be useful to create mechanisms that allow the sharing of opinions between members of the FP, with the delegate as a key actor to increase with the other police officers a sense of responsibility in relation to firearms.

In theoretical terms this study contributes directly to the knowledge about scales to measure individuals' perception about firearms. The results reinforce the consistency of the ATGS scale, generating more evidence of its ability to measure the perception of individuals about firearms. In this regard, the findings corroborate previous studies, especially Nascimento et al. (2016), who showed that ATGS is adequate to measure the attitude of military police officers on firearms. The new evidence provided by the present study on the adequacy of the scale with the Federal Police officers is another step for this measure to be obtained from all types of police officers existing in Brazil, thus forming a general picture on the subject.

The results are also relevant for the elaboration and implementation of public policies in Brazil regarding firearms control. Federal Police officers, especially the delegates, are central players in this context. As 'street-level bureaucrats', they can significantly influence the policies outcomes (Lipsky, 1980 ) and their values and beliefs can influence the implementation of public policies (Ferreira \& Medeiros, 2016; Lipsky, 1980; Maynard-Moody \& Musheno, 2012). Thus, if the values and attitudes of police officers towards firearms are different from the values of the arms control policy in which they are responsible for implementation, the police officers may show resistance to the guidelines that accompany the delegation and, therefore, deviate from the norms and formal procedures (Oliveira, 2012). Therefore, designing such policies without knowing the beliefs and values of these professionals may be a simplistic strategy.

\section{CONCLUSION AND FINAL CONSIDERATIONS}

The question that motivated this research is the following: what is the attitude of Brazilian Federal Police officers towards firearms? In general, it can be concluded that the Federal Police officers investigated believe that the possession of firearms is an individual right. However, they also believe that firearms do not protect against crime. It can also be concluded, based on the results found, that the police officers' attitude towards firearms is influenced by the position and experience of the police officer with firearms. In other words, according to the position held at the FP and their history with firearms, the interviewees show a more or less positive attitude towards firearms.

This research has limitations. The first one refers to the impossibility of generalizing the results to all Federal Police officers, considering that the sampling selection process was not random. Even though the access link has been forwarded to all active police officers, and the respondents' highly diversified profile, with representation of all subsets of the population, the results need to be contextualized. Another limitation refers to the variables that express the dimensions of the experience of police officers with firearms. Although these variables were chosen based on the literature review, the 
RAP | The attitude of Brazilian federal police officers towards firearms

non-adoption of a scale with evidence of psychometric validity subjected the results to the analysis of the impact of the common variance.

As a recommendation for further studies, we suggest that the scale used in this work be tested with military police officers from different Brazilian states, in order to investigate the influence of social context, culture and local norms on military police officers' attitude towards firearms. Likewise, we suggest applying the scale to civil police officers from different Brazilian states. The results of the different studies could be compared, thus allowing the elaboration of a general picture with the attitudes of the different types of Brazilian police officers in relation to firearms. Still as a recommendation for further studies, it would be important to investigate how the attitude of Federal Police influences the conduct of the firearms control policy in the country. For example, it could be investigated whether delegates with more positive attitudes tend to approve and issue more firearms records than delegates with less positive attitudes. 


\section{REFERENCES}

Andrés, A. R., \& Hempstead, K. (2011). Gun control and suicide: The impact of state firearm regulations in the United States, 1995-2004. Health Policy, 101(1), 95-103. Retrieved from https://doi. org/10.1016/j.healthpol.2010.10.005

Anglemyer, A., Horvath, T., \& Rutherford, G. (2014). The accessibility of firearms and risk for suicide and homicide victimization among household members: A systematic review and meta-analysis. Annals of Internal Medicine, 160(2), 101-110. Retrieved from https://doi.org/10.7326/M13-1301

Arnold, H. J., \& Feldman, D. C. (1982). A multivariate analysis of the determinants of job turnover. Journal of Applied Psychology, 67(3), 350-360. Retrieved from https://doi.org/10.1037/0021-9010.67.3.350

Azrael, D., Cohen, J., Salhi, C., \& Miller, M. (2018). Firearm Storage in Gun-Owning Households with Children: Results of a 2015 National Survey. Journal of Urban Health, 95(3), 295-304. Retrieved from https://doi.org/10.1007/s11524-018-0261-7

Branscombe, N. R., Weir, J. A., \& Crosby, P. (1991). A three-factor scale of attitudes toward guns. Aggressive Behavior, 17(5), 261-273. Retrieved from https:// doi.org/10.1002/1098-2337(1991)17:5<261::AIDAB2480170503>3.0.CO;2-8

Brown, T. A. (2006). Confirmatory Factor Analysis for applied research. New York, NY: Guildford.

Byrne, B. M. (2010). Structural Equation Modeling with AMOS: basic concepts, applications, and programming. Ontario, Canada: Routledge.

Caneda, C. R. G., \& Teodoro, M. L. M. (2010). Desenvolvimento e Investigação de Propriedades Psicométricas da Escala Motivacional para Porte de Arma (EMPA). Avaliação Psicológica, 9(3), 471-478.

Cerqueira, D. (2018). Atlas da Violência 2018. Rio de Janeiro, RJ: Instituto de Pesquisa Econômica Aplicada e Forum Brasileiro de Segurança Pública.

Cerqueira, D. R. C. (2014). Causas e consequências do crime no Brasil. Rio de Janeiro, RJ: BNDES

Crifasi, C. K., Merrill-Francis, M., McCourt, A., Vernick, J. S., Wintemute, G. J., \& Webster, D. W. (2018). Association between Firearm Laws and Homicide in Urban Counties. Journal of Urban Health, 95(3), 383-390. Retrieved from https://doi. org/10.1007/s11524-018-0273-3
Costa, D. H., Njaine, K., \& Schenker, M. (2017). Repercussões do homicídio em famílias das vítimas: Uma revisão da literatura. Ciencia e Saude Coletiva, 22(9), 3087-3097. Retrieved from https://doi. org/10.1590/1413-81232017229.18132016

Diez, C., Kurland, R. P., Rothman, E. F., Bair-Merritt, M., Fleegler, E., Xuan, Z., ... \& Siegel, M. (2017). State intimate partner violence-related firearm laws and intimate partner homicide rates in the United States, 1991 to 2015. Annals of Internal Medicine, 167(8), 536-543. Retrieved from https:// doi.org/10.7326/M16-2849

Domingues, D. F., \& Dessen, M. A. (2013). Reorganização familiar e rede social de apoio póshomicídio juvenil. Psicologia: Teoria e Pesquisa, 29(2), 141-148. Retrieved from https://doi.org/10.1590/ S0102-37722013000200003

Domingues, D. F., Villas Boas, A. C. V. B., \& Dessen, M. A. (2011). Homicídio juvenil por arma de fogo e reorganização familiar um estudo de caso. Psico, 42(1), 51-58.

Fernandes, A. (2014). Vitimização policial: análise das mortes violentas sofridas por integrantes da Polícia Militar do Estado de São Paulo (2013-2014). Retrieved from http://hdl.handle.net/10438/16335

Ferreira, V., \& Medeiros, J. (2016). Fatores que moldam o comportamento dos burocratas de nível de rua no processo de implementação de políticas públicas. Cadernos EBAPE.BR, 14(3), 776-793.

Frederickson, G., Smith, K., Larimer, C., \& Licari, M. (2010) The Public Administration Theory Primer (Sec. Ed.). Boulder, CO: Westview Press.

Hair, J. F., Anderson, R. E., Tatham, R. L., \& Black, W. C. (2009). Análise multivariada de dados. Porto Alegre, RS: Bookman.

Hamill, M. E., Hernandez, M. C., Bailey, K. R., Zielinski, M. D., Matos, M. A., \& Schiller, H. J. (2019). State Level Firearm Concealed-Carry Legislation and Rates of Homicide and Other Violent Crime. Journal of the American College of Surgeons, 228(1), 1-8. Retrieved from https://doi.org/10.1016/j. jamcollsurg.2018.08.694

Kalesan, B., \& Galea, S. (2017). Patterns of gun deaths across US counties 1999-2013. Annals of Epidemiology, 27(5), 302-307.e3. Retrieved from https://doi.org/10.1016/j.annepidem.2017.04.004 
Kaufman, E. J., Morrison, C. N., Branas, C. C., \& Wiebe, D. J. (2018). State firearm laws and interstate firearm deaths from homicide and suicide in the United States a cross-sectional analysis of data by county. JAMA Internal Medicine, 178(5), 692-700. Retrieved from https://doi.org/10.1001/ jamainternmed.2018.0190

Keil, S., Beardslee, J., Schubert, C., Mulvey, E., \& Pardini, D. (2019). Perceived Gun Access and Gun Carrying Among Male Adolescent Offenders. Youth Violence and Juvenile Justice, 18(2), 179-195. Retrieved from https://doi.org/10.1177/1541204019865312

Keinert, R., Fonseca, F., Blikstein, I., Storino, F., \& Sano, H. (2005). Armas de Fogo no Brasil. São Paulo, SP: Fundação Getulio Vargas.

Lima, L. L., \& D’Ascenzi, L. (2013). Implementação de políticas públicas: perspectivas analíticas. Revista De Sociologia e Política, 21(48), 101-110. Retrieved from https://doi.org/10.1590/S010444782013000400006

Lipsky, M. (1980). Street-Level Bureaucracy: Dilemmas of the Individual in Public Services. New York, NY: Russell Sage.

Maciel, P. R., Souza, M. R., \& Rosso, C. F. W. (2016). Estudo descritivo do perfil das vítimas com ferimentos por projéteis de arma de fogo e dos custos assistenciais em um hospital da Rede Viva Sentinela. Epidemiologia e Serviços de Saúde: Revista Do Sistema Unico de Saude Do Brasil, 25(3), 607-616. Retrieved from https://doi.org/10.5123/ S1679-49742016000300016

Malta, D. C., Minayo, M. C. S., Soares, A. M., Filho, Silva, M. M. A., Montenegro, M. de M. S., Ladeira, R. M., ... Naghavi, M. (2017). Mortalidade e anos de vida perdidos por violências interpessoais e autoprovocadas no Brasil e Estados: análise das estimativas do Estudo Carga Global de Doença, 1990 e 2015. Revista Brasileira de Epidemiologia, 20(suppl 1), 142-156. Retrieved from https://doi. org/10.1590/1980-5497201700050012

Manley, N. R., Fabian, T. C., Sharpe, J. P., Magnotti, L. J., \& Croce, M. A. (2018). Good news, bad news: An analysis of 11,294 gunshot wounds (GSWs) over two decades in a single center. Journal of Trauma and Acute Care Surgery, 84(1), 58-65. Retrieved from https://doi.org/10.1097/TA.0000000000001635

Marôco, J. (2010). Análise de equações estruturais: Fundamentos teóricos, software \& aplicações. Pêro Pinheiro, Portugal: Report Number.
Maynard-Moody, S., \& Musheno, M. (2012). Social equities and inequities in practice: streetlevel workers as agents and pragmatists. Public Administration Review, 72(51), S16-S23.

Mello-Silva, A. C. C., Brasil, V. V., Minamisava, R., Oliveira, L. M. A. C., Cordeiro, J. A. B. L., \& Barbosa, M. A. (2012). Qualidade de Vida e Trauma Psíquico em Vítimas da Violência por Arma de Fogo. Texto e Contexto Enfermagem, 21(3), 558-565. Retrieved from https://doi.org/10.1590/S010407072012000300010

Miller, M., Hepburn, L., \& Azrael, D. (2017). Firearm acquisition without background checks: Results of a national survey. Annals of Internal Medicine, 166(4), 233-239. Retrieved from https://doi.org/10.7326/ M16-1590

Nascimento, T. G., Pimentel, C. E., \& AdaidCastro, B. G. (2016). Escala de Atitudes frente à Arma de Fogo (EAFAF): Evidências de Sua Adequação Psicométrica. Psicologia: Teoria $e$ Pesquisa, 32(1), 239-248. Retrieved from https://doi. org/10.1590/0102-3772201602187239248

Nascimento, T. G., Souza, E. C., \& Adaid-Castro, B. G. (2020). Escalas de competências profissionais para policiais: evidências de sua adequação psicométrica. Revista de Administração Pública, 55(1), 99-120.

Oliveira, A. (2012). Burocratas da linha de frente. Executores e fazedores das políticas públicas. Revista de Administração Pública, 46(6), 1551-73.

Paper, W., Oliveira, C., Federal, U., \& Grande, R. (2017, June). Mais armas de fogo, mais homicídios? Uma evidência empírica para a Região Metropolitana de Porto Alegre a partir de dados em painel (Working Paper). Retrieved from https://doi.org/10.13140/ RG.2.2.21291.64803

Pasquali, L. (2012). O Uso da Análise Fatorial: Algumas Diretrizes para Pesquisadores. In L. Pasquali (Ed.), Análise Fatorial Para Pesquisadores (pp.141-160). Brasília, DF: LabPAM Saber e Tecnologia.

Prandi, R., \& Santos, R. W. (2017). Quem tem medo da bancada evangélica? Posições sobre moralidade e política no eleitorado brasileiro, no congresso nacional e na frente parlamentar evangélica. Tempo Social, 29(2), 187-214. Retrieved from https://doi. org/10.11606/0103-2070.ts.2017.110052 
Ribeiro, A. P., Souza, E. R., \& Sousa, C. A. M. (2017). Lesões provocadas por armas de fogo atendidas em serviços de urgência e emergência brasileiros. Ciência \& Saúde Coletiva, 22(9), 28512860. Retrieved from https://doi.org/10.1590/141381232017229.16492017

Sanches, S., Duarte, S. J. H., \& Pontes, E. R. J. C. (2009). Caracterização das vítimas de ferimentos por arma de fogo, atendidas pelo serviço de atendimento móvel de urgência em campo Grande-MS. Saúde e Sociedade, 18(1), 21-28. Retrieved from https://doi. org/10.1590/S0104-12902009000100010

Santaella-Tenorio, J., Cerdá, M., Villaveces, A., \& Galea, S. (2016). What Do We Know about the Association between Firearm Legislation and Firearm-Related Injuries? Epidemiologic Reviews, 38(1), 140-157. Retrieved from https://doi. org/10.1093/epirev/mxv012

Santos, R. (2012). Cidadãos de bem" com armas: Representações sexuadas de violência armada, (in) segurança e legítima defesa no Brasil. [Good Citizens with Weapons: Sexualized Representations of Armed Violence], (In)security and Legitimate Defense in Brazil « Citoyens comme il. Revista Crítica de Ciências Sociais, 96, 133-164. Retrieved from https:// doi.org/10.4000/rccs.4851

Shapiro, J. P., Dorman, R. L., Burkes, W. M., Welker, C. J., \& Clough, J. B. (1997). Development and factor analysis of a measure of youth attitudes toward guns and violence, 26(3), 311-320. Retrieved from https:// doi.org/10.1207/s15374424jccp2603

Siegel, M., Negussie, Y., Vanture, S., Pleskunas, J., Ross, C. S., \& King, C. (2014). The relationship between gun ownership and stranger and nonstranger firearm homicide rates in the United States, 19812010. American Journal of Public Health, 104(10), 1912-1919. Retrieved from https://doi.org/10.2105/ AJPH.2014.302042

Siegel, M., Ross, C. S., \& King, C. (2013). The relationship between gun ownership and firearm homicide rates in the United States, 1981-2010. American Journal of Public Health, 103(11), 20982105. Retrieved from https://doi.org/10.2105/ AJPH.2013.301409

Stroebe, W. (2016). Firearm Availability and Violent Death: The Need for a Culture Change in Attitudes toward Guns. Analyses of Social Issues and Public
Policy, 16(1), 7-35. Retrieved from https:/doi. org/10.1111/asap.12100

Swedler, D. I., Simmons, M. M., Dominici, F., \& Hemenway, D. (2015). Firearm prevalence and homicides of law enforcement officers in the United States. American Journal of Public Health, 105(10), 2042-2048. Retrieved from https://doi.org/10.2105/ AJPH.2015.302749

Tabachnick, B. G., \& Fidell, L. S. (2014). Using multivariate statistics. Retrieved from https:// hollilermalemi.files.wordpress.com/2017/05/usingmultivariate-statistics-5th-edition-by-barbara-gtabachnick-linda-s-fidell.pdf

Thompson, A., Price, J. H., Dake, J. A., \& Tatchell, T. (2006). Police chiefs' perceptions of the regulation of firearms. American Journal of Preventive Medicine, 30(4), 305-312.e3. Retrieved from https://doi. org/10.1016/j.amepre.2005.11.009

Todeschini, A. B., Veiga, J. C. E., Souza, R. B., Saade, N., \& Aguiar, G. B. (2013). Traumatismo cranioencefálico por projétil de arma de fogo: experiência de 16 anos do serviço de neurocirurgia da Santa Casa de São Paulo. Revista do Colégio Brasileiro de Cirurgiões, 40(4), 300-304. Retrieved from https:// doi.org/10.1590/s0100-69912013000400008

Trindade, R. F. C., Costa, F. A. M. M., Silva, P. P. A. C., Caminiti, G. B., \& Santos, C. B. dos. (2015). Map of homicides by firearms: Profile of the victims and the assaults. Revista da Escola de Enfermagem, 49(5), 748-755. Retrieved from https://doi.org/10.1590/ S0080-623420150000500006

Tseng, J., Nuño, M., Lewis, A. V., Srour, M., Margulies, D. R., \& Alban, R. F. (2018). Firearm legislation, gun violence, and mortality in children and young adults: A retrospective cohort study of 27,566 children in the USA. International Journal of Surgery, 57, 30-34. Retrieved from https://doi. org/10.1016/j.ijsu.2018.07.010

Wombacher, C., \& Wallace, L. N. (2019). Childhood gun socialization among college-educated youth: Shaping adult attitudes. Social Science Journal, 56(3), 349-357. Retrieved from https://doi.org/10.1016/j. soscij.2018.08.005

Zandominighi, R. C., Martins, E. A. P., \& Mouro, D. L. (2011). Ferimento por projétil de arma de fogo: Um problema de saúde pública. Rev. Min. Enferm., 15(3), 412-420. 


\section{Alessandra Borba}

https://orcid.org/0000-0002-7344-4062

Master's in public administration from the University of Brasília (UnB); Delegate of the Federal Police.

E-mail: alessandra.ab@dpf.gov.br

\section{Adalmir de Oliveira Gomes}

https://orcid.org/0000-0001-9000-3296

Ph.D. in Administration from the University of Brasília (UnB); Adjunct Professor of the Graduate Program in Administration at the University of Brasília (PPGA/UnB).E-mail: adalmir@unb.br 